\section{РОЗВИТОК БУХГАЛТЕРСЬКОГО
ОБЛІКУ У СИСТЕМІ ПРИЙНЯТТЯ \\ РОЗВИТОК БУХГАЛТЕРСЬКОГО
ОБЛІКУ У СИСТЕМІ ПРИЙНЯТТЯ УПРАВЛІНСЬКИХ РІШЕНЬ: ІСТОРИЧНИЙ АСПЕКТ ${ }^{\odot}$}

\author{
ПРОДАНЧУК М.А., \\ доктор економічних наук, доцент, \\ Відмінник освіти Украӥни, \\ ННЦ «нститут аграрної економіки» \\ НААН Украӥни, \\ (м. Kиїв)
}

В статті досліджено історію етапів виникнення та становлення бухгалтерського обліку в управлінні підприємством в різних країнах світу із врахуванням вітчизняного досвіду, а також визначено його розвиток у забезпеченні прийняття стратегічних рішень. За результатами дослідження з'ясовано, у країнах світу немає єдиного підходу трактування "управлінський облік". Обгрунтовано, щзо лише для англомовних країн, поняття "управлінський облік" $\epsilon$ загальноприйнятим. Визначено, щзо термін "управлінський облік" - неправильний переклад словосполучення "Management accounting", щзо буквально означає "управлінське рахівництво", а не управлінський облік. Зазначене дало можливість уточнити сучасне розуміння управлінського обліку, яке зводиться до розкриття його першої частини, тобто акиентування уваги на слові "управлінський", оскільки саме це означення розкриває змістовне наповнення того, щуо очікують від такого обліку та для чого він призначений.

Визначено, щуо розвиток управлінського обліку відбувається в міждисциплінарному напрямку. Теорія систем i аналіз, право, економічна кібернетика, математика, теорія ймовірності, моделювання, моделі й методи прийняття рішень, інформаційні технології та програмування. Така синергетика сприяє посиленню бухгалтерського обліку в управлінні бізнесом підприємств.

Дослідження історичної еволючії управлінської складової обліку дозволило виявити закономірності його становлення та сприяло виокремленню иести етапів його розвитку в управлінні. Виділені етапи становлення бухгалтерського обліку віддзеркалюють розвиток його організації й методології в управлінні, тим самим засвідчуючи появу нових постійно зростаючих вимог як до обліку, так і до його даних.

Ключові слова: бухгалтерський облік, управлінський облік, система управління, маржинальна бухгалтерія, стратегічне управління.

Рис. 2. Літ: 12.

\title{
DEVELOPMENT OF ACCOUNTING IN THE SYSTEM OF MAKING MANAGERIAL DECISIONS: HISTORICAL ASPECT
}

\author{
PRODANCHUK Mykhailo, \\ Doctor of Economic Sciences, \\ Associate Professor of State Audit and Control Department \\ NSC "Institute of Agrarian Economics" \\ NAAS of Ukraine \\ (Kyiv)
}

The article investigates the history of stages of emergence and formation of accounting in enterprise management in different countries of the world, taking into account domestic experience, and also determines its development in ensuring strategic decision-making. According to the results of the study, it is found that in the countries of the world there is no single approach of interpretation of "management accounting". It is justified that for English-speaking countries only, the concept of "management accounting" is generally accepted. It is determined that the term "management accounting" is a misinterpretation of the phrase "Management accounting", which literally means "management accounting", not management accounting. This made it possible to clarify the modern understanding of management accounting, which comes down to the disclosure of its first part, that is, the emphasis on the word "managerial", because it is this definition reveals a meaningful content of what is expected of such accounting and what it is intended for. 


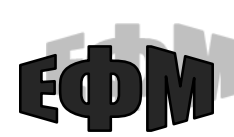

http://efm.vsau.org/

It is determined that the development of management accounting is in an interdisciplinary direction. Systems theory and analysis, law, economic cybernetics, mathematics, probability theory, modeling, models and decision-making methods, information technology and programming. Such synergetics helps to strengthen accounting in business management of enterprises.

The study of the historical evolution of management accounting component revealed the patterns of its formation and helped to highlight the six stages of its development in management. Selected stages of accounting form reflect the development of its organization and methodology in management, thereby attesting to the emergence of new ever-growing requirements for both accounting and its data.

Keywords: accounting, management accounting, management system, margin accounting, strategic management.

Fig.: 2. Lit.: 12.

\title{
РАЗВИТИЕ БУХГАЛТЕРСКОГО УЧЕТА В СИСТЕМЕ ПРИНЯТИЯ УПРАВЛЕНЧЕСКИХ РЕШЕНИЙ: ИСТОРИЧЕСКИЙ АСПЕКТ
}

\author{
ПРОДАНЧУК М.А., доктор экономических наук, доцент, \\ Отличник образования Украины, \\ ННЦ «Институт аграрной экономики» \\ НААН Украины, \\ (2. Киев)
}

\begin{abstract}
В статье исследована история этапов возникновения и становления бухгалтерского учета в управлении предприятием в различных странах мира с учетом отечественного опыта, а также определены его развитие в обеспечении принятия стратегических решений. По результатам исследования установлено, что в странах мира не существует единого подхода трактовка "управленческий учет". Обосновано, что только в англоязычных странах, понятие "управленческий учет" является общепринятылм. Определено, что термин "управленческий учет" - неправильный перевод словосочетания "Management accounting", что буквально озбозначает "управленческое счетоводство», а не управленческий учет. Указанное позволило уточнить современное понимание управленческого учета, которое сводится к раскрытию его первой части, то есть акцентирование внимания на слове "управленческий", поскольку именно это определение раскрывает содержательное наполнение того, что ожидают от такого учета и для чего он предназначен.

Определено, что развитие управленческого учета происходит в междисциплинарном направлении. Теория систем и анализ, право, экономическая кибернетика, математика, теория вероятности, моделирование, модели и методы принятия решений, информачионные технологии и программирование. Такая синергетика способствует усилению бухгалтерского учета в управлении бизнесом предприятий.

Исследование исторической эволючии управленческой составляющей учета позволило выявить закономерности его становления и способствовало выделению шести этапов его развития в управлении. Выделенные этапы становления бухгалтерского учета отражают развитие его организаџии и методологии в управлении, тем самым свидетельствуя появление новых постоянно растущих требований как к учету, так и кего данным.
\end{abstract}

Ключевые слова: бухгалтерский учет, управленческий учет, система управления, маржинальная бухгалтерия, стратегическое управление.

Рис.: 2. Лит.: 12.

Постановка проблеми. Розвиток науки передбачає певну активність дослідницької думки. Нове знання $є$ конструктивною діяльністю, що характеризує творче зусилля суб'єктів. Наука повинна розширювати свої пізнавальні межі та адаптуватися до потреб суспільства. Визначальною ознакою розвитку облікової системи є конкретизація ролі обліку в економічному житті суспільства.

Система бухгалтерського обліку орієнтована переважно на інформаційні потреби зовнішніх споживачів і не в повній мірі відповідає запитам системи управління бізнесом підприємства. Тому одним із ключових моментів на сьогодні $є$ визначення змісту обліку, що забезпечуватиме потреби управління, тобто формування інформаційної системи з метою прийняття обгрунтованих рішень, а також визначення напрямів стратегічного розвитку бізнесу підприємства в майбутньому. А це, у свою чергу, має визначити потребу в розвитку бухгалтерського обліку, методологія якого повинна реагувати на зміни стратегій менеджменту.

Аналіз останніх досліджень та публікацій. Значний внесок в розвиток бухгалтерського обліку в управлінні підприємством в своїх публікаціях приділяли наступні вітчизняні та зарубіжні автори: А.М. Галаган [1], М.В. Дмитрієв [2], М.Р. Лучко [3], М.Р. Метьюс [4], Б. Нідлз [5], С.А. Ніколаєва [6], А.П. Рудановський [8], Я.В. Соколов [9], Н. Г. Чумаченко [10]. 
Формулювання цілей статті $є$ дослідження історії етапів виникнення та становлення бухгалтерського обліку в управлінні підприємством в різних країнах світу із врахуванням вітчизняного досвіду, а також визначення його розвитку у забезпеченні прийняття стратегічних рішень.

Виклад основного матеріалу дослідження. Роль і місце бухгалтерського обліку в бізнесі та перспективи подальшого його розвитку можна виявити за допомогою історичного аналізу, що має спрямовуватися на відкриття зв'язків та причин, відповідно до яких цей розвиток відбувається. Історія бухгалтерського обліку охоплює період тривалістю майже шість тисяч років. Невід'ємною частиною цієї історії була еволюція розвитку управлінського обліку, його практики і теорії. При розкритті історичної еволюції облікової складової в системі управління підприємством головним має бути не саме відтворення його історії, а виявлення факторів, що зумовили перехід від однієї стадії розвитку до іншої.

Перші спроби заснування бухгалтерського обліку зафіксовано в період до нашої ери, коли на базальтовому стовпі було викарбовано закони царя Вавилону Хаммурапі, в яких йшлося про витрати на виробництво продукції, орендну плату та прибутки від діяльності господарства. Цей етап $є$ початковим, свідчить про започаткування бухгалтерського обліку в управлінні та охоплює часовий проміжок до XV ст.

Наступним $є$ етап становлення бухгалтерського обліку в управлінні (XV - кінець XIX ст.). Його формування розпочалося $з$ опублікування однієї з перших праць, присвячених питанням управлінського обліку, - книги "Трактат про рахунки і записи" італійського монаха й математика Луки Пачолі. В цій науковій праці, робота над якою тривала впродовж 1445-1515 pp., запропоновано окремі класифікаційні ознаки для розподілу витрат щодо підприємства, товару і господарського процесу.

Означені часові межі підтверджує також позиція Б. Нідлза, Х. Андерсона і Д. Колдуелла, які у книзі "Принципи бухгалтерського обліку" зазначають, що 1494 рік є початком розвитку управлінського обліку [5, с. 9]. Саме в цей період здійснюються спроби обгрунтування та застосування на практиці розподілу витрат на виробничі та невиробничі. Доказом цього слугують книги Г. Грамматеуса "Коротка книга з мистецтва і знання всіх випадків комерційної практики" (1521р.) та Д. Манчіні "Подвійна книга з їі Журналом, яка складена в останній час і старанно викладена за Венеціанським звичаєм" (1534 р.) [7, с. 273-274].

На теренах колишнього СРСР становленню бухгалтерського обліку в управлінні приділялася не менша увага. Вагомим внеском у розвиток бухгалтерського обліку в управлінні стала книга Е.О. Мудрова "Счетоводство для всех родов торговли" (1848 р.), вихід якої Я.В. Соколов назвав видатною подією в історії російської облікової думки [9, с. 305]. Російський учений М. Дмитрієв писав: "Для початкового періоду НЕПу характерним було існування в трестах... галузей промисловості двох бухгалтерій - фінансової та бухгалтерії з обліку виробництва і калькулювання собівартості продукції" [2, с. 19]. Іноземні вчені, які досліджували систему обліку в СРСР, зазначали: "Всю систему обліку за комуністичного режиму представляє те, що ми називаємо обліком управлінським" [4, с. 557]. Виявляється, що саме традиційний бухгалтерський облік ще в ті часи мав елементи управлінського.

Етап розвитку базового бухгалтерського обліку в управлінні охоплює період з кінця XIX ст. до 30 pp. XX ст. На початку XX ст., в умовах наростання конкуренції, розвитку технологічних та організаційних процесів, збільшення частки в економіці промислових підприємств машинобудівного виробництва, виникла потреба формування механізму облікової інформації про деталізацію витрат, давала би змогу приймати управлінські рішення. У цей час учені проводили поглиблені наукові дослідження щодо удосконалення бухгалтерського обліку, що характеризує виникнення управлінського обліку саме в цьому періоді як однієї з його складових.

У 1912 р. Ч. Гаррісон опублікував концепцію обліку, що одержала назву "стандарт-кост", яка спочатку мала різні назви, зокрема "кошторисна собівартість", "нормативна собівартість" та ін. Ця система формувалась як основний інструмент управління і реалізувала себе на практиці на підприємствах різного профілю як управлінська, а не облікова система.

За цим ученим, система "стандарт-кост" базується на двох правилах:

- витрати мають бути зіставлені зі стандартами;

- $\quad$ виявлені відхилення мають бути розмежовані за причинами.

Розроблена облікова система "стандарт-кост" на підставі відхилень від норм (стандартів) давала змогу не тільки фіксувати минулі події, а й визначати орієнтири на майбутнє, щоб приймати оперативні управлінські рішення. Отже, Г. Емерсон і Ч. Гаррісон заклали основу управлінського обліку як однієї зі складових бухгалтерського. 
Значний внесок у розвиток даної системи також зробив М.Х. Жебрак, який у 1934 р. керував іiї впровадженням в практичну діяльність низки машинобудівних підприємств. Такий досвід сприяв збагаченню наукових ідей щодо нормативного методу обліку витрат.

3 огляду на особливості ведення аграрного бізнесу, прийняття ефективних управлінських рішень неможливе без ведення бухгалтерського обліку за окремими видами продукції, структурними підрозділами та по підприємству в цілому. Починаючи з 1932 р., принцип організації обліку за нормами "стандарт-кост" поступово почали впроваджувати і в аграрних підприємствах України. У 1981 р. для них було рекомендовано випробуваний у промисловості прогресивний нормативний метод обліку витрат, що масово застосовувався в розвинутих країнах.

Вагомий внесок у розвиток бухгалтерського обліку в управлінні належить також вітчизняним вченим, зокрема:

- Р.Я. Вейцману, який доводив необхідність розподілу витрат за видами продукції;

- С.Ф. Іванову, який наполягав на включенні до собівартості продукції лише прямих витрат;

- О.П. Рудановському, який обгрунтовував необхідність покриття непрямих витрат саме за рахунок отриманого прибутку [5];

- О.М. Галагану, який намагався трансформувати накладні витрати у прямі для більш точного обчислення вартості виробленої продукції [1].

Два останні науковці фактично стояли біля керма всієї бухгалтерської науки тодішньої Російської імперії і продовжували свої пошуки аж до 30-х рр. ХХ ст. [3, с. 86]. На думку Я.В. Соколова, саме О.П. Рудановський одним із перших запропонував визначати не тільки фактичну собівартість продукції, а й нормативну, що дало поштовх розвитку нормативного методу обліку в нашій країні [9, с. 287]. Слід зазначити, що в Україні систему нормативного методу обліку було вперше впроваджено на Харківському заводі "Серп і молот".

Створення в 1919 р. під керівництвом Дж. Лі Нікольсона в США Національної асоціації бухгалтерів-виробників сприяло виділенню управлінського обліку в самостійну галузь бухгалтерської практики. Пізніше, в 1972 р., Асоціація стала засновником Інституту управлінського обліку і відіграла важливу роль у його розвитку в США. Отже, базовий управлінський облік виник у країнах 3 високорозвинутою економікою ще на початку 20-х рр. XX ст.

У період 40 - 50-х рр. XX ст. формується черговий етап розвитку бухгалтерського обліку в управлінні, який отримав назву маржинальної бухгалтерії. Протягом цього періоду в країнах Заходу i Сполучених Штатах Америки впроваджується система обліку за центрами відповідальності та калькулювання змінних витрат - "директ-костинг". Мета його формулювалася як надання інформації управлінцям, контроль і прогнозування витрат, вибір найбільш ефективних оперативних управлінських рішень [6].

Серед учених-економістів не склалося одностайної думки щодо того, хто був основоположником цієї системи. У розвиток ідей директ-костингу вагомим є внесок Ж. КурсельСенеля, Г. Гесса, Дж. Кларка, О. Шмаленбаха. Подальше дослідження проводили Джон Х. Уільямс, Чарльз М. Кнопель, Ч.Т. Хорнгрен, Дж. Фостер, Рей Ван дер Віль, Д. Бернер.

Практичне впровадження цього методу в США було започатковано у 1953 р., пізніше він поширився у Франції - маржинальна бухгалтерія, та у Великобританії - маржинальна калькуляція. Нині метод "директ-костинг" застосовується у багатьох економічно розвинутих країнах.

У цей період на теренах колишнього Радянського Союзу для введення галузевого принципу в управління економікою з метою покращення обліку витрат на виробництво у 60 - 70-ті pp. минулого століття було видано і затверджено низку документів, які стосувалися нормативного методу обліку витрат переважно промислових підприємств.

П'ятий етап - розвиток управлінського обліку як науки - охоплює 70 - 95 pp. ХХ ст. На 70-ті роки минулого століття припадає основний етап розвитку управлінського обліку як науки. Виникають нові технології обробки бухгалтерської інформації, з метою оптимізації управління бізнес-процесами для обробки облікових даних використовується електронно-обчислювальна техніка. У цей період (1972 р.) Національною асоціацією бухгалтерів США була розроблена перша програма з управлінського обліку. Цей рік ознаменувався тим, що Асоціацією було підготовлено фахівців 3 управлінського обліку із присвоєнням кваліфікації бухгалтера-аналітика. В університетах США цей облік починають вивчати як обов'язковий курс.

Наукове дослідження про управлінський облік у США побачило світ у 1971 р. під авторством академіка НАН України М. Чумаченка, де він зазначав: "П'ятдесяті та шістдесяті роки в США відзначаються підвищеним інтересом до питань обліку виробничих витрат і калькулювання 
собівартості. Змінилися функції та зміст обліку. Поняття "облік виробництва" (cost accounting) у п'ятдесяті роки дедалі частіше почали замінювати поняттям "управлінський облік" (management accounting)" [10, c. 4]. Переорієнтація обліку з виробничого на управлінський головним чином пов'язана з трансформацією підходів до керівництва не лише виробництвом, а й іншою діяльністю підприємства, бажанням не стільки мати інформацію про здійснені господарські факти, скільки їх спрогнозувати на основі складання попередніх кошторисів, проведення систематичного аналізу витрат тощо.

За результатами дослідження з'ясовано, що на сьогодні не існує однозначного тлумачення поняття "управлінський облік". Одні автори вважають, що існуючі визначення за змістом $є$ рівнозначними, інші намагаються довести, що між ними є складні системи взаємозв'язків. Назва "управлінський облік" (Management Accounting) широко використовується в англомовній літературі з обліку та аудиту. Однак у країнах світу немає єдиного підходу його трактування. Поняття "управлінський облік" є загальноприйнятим для англомовних країн, тоді як, наприклад, у Франції цю підсистему обліку називають маржинальним обліком, а німецькі фахівці іiї зміст вкладають у поняття "контролінг". Як зазначає ряд дослідників, термін "управлінський облік" неправильний переклад словосполучення "Management accounting", що буквально означає "управлінське рахівництво"[11, с. 825], а не управлінський облік.

Сучасне розуміння управлінського обліку зводиться до розкриття його першої частини, тобто акцентується увага на слові "управлінський", оскільки саме це означення розкриває змістовне наповнення того, що очікують від такого обліку та для чого він призначений.

Американські вчені зазначали, що те, до чого прагнув управлінський облік, містилося в споріднених областях: економіці, математиці, статистиці, психології, ринкових операціях, технології. "Він повинен був запозичувати дещо від кожної з них, і в результаті з'явилась нова область - управлінський облік" [12]. Цей перелік можна доповнити іншими науками: математика, теорія ймовірності, економіка, економічна кібернетика, фінанси, маркетинг, статистика, психологія, право. Вплив згаданих сфер діяльності на формування системи управлінського обліку відображено на рис. 1.

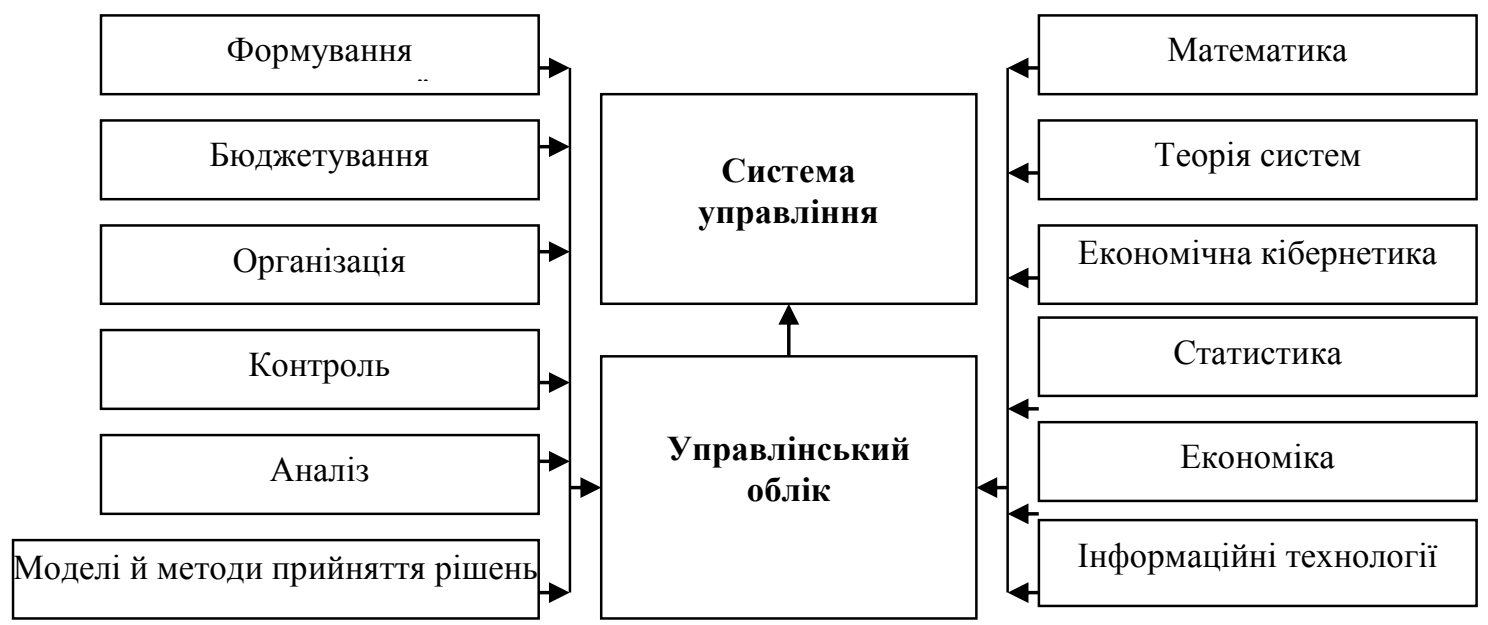

Рис. 1. Вплив сфер діяльності на формування системи управлінського обліку

Джерело: сформовано автором

Розвиток управлінського обліку має відбуватися в міждисциплінарному напрямку. Теорія систем і аналіз, економічна кібернетика, моделювання, моделі й методи прийняття рішень, інформаційні технології та програмування, синергетика мають посилити бухгалтерський облік в управлінні бізнесом підприємств.

Для забезпечення прийняття ефективних управлінських рішень деталізацію та підготовку облікової інформації слід здійснювати з урахуванням вимог управлінського персоналу. Ця інформація в подальшому здатна ефективно підвищувати функціонування системи менеджменту суб'єкта господарювання, адже безпідставно деталізована інформація втрачає інтерес і використовується формально.

Останній етап - розвиток бухгалтерського обліку для забезпечення стратегічного управління розпочався в 90-х pp. ХX ст. і триває й дотепер. У 90-х роках XX ст., в умовах глобальних змін у технологіях i системах управління, зріс інтерес до бухгалтерського обліку з боку менеджерів різних галузей економіки та рівнів управління, що посилює роль бухгалтерського обліку в стратегічному управлінні. 
У цей період вітчизняні науковці приділяють велику увагу дослідженню теоретичних $\mathrm{i}$ практичних аспектів управлінського обліку. Серед них Ф.Ф. Бутинець, С.Ф. Голов, Б.І. Валуєв, В.Г. Лінник, Г.Г. Кірейцев, Л.В. Нападовська, В.В. Сопко, М.Г. Чумаченко та ін. У цей період у вищих закладах освіти навчальними програмами з підготовки спеціалістів економічного напряму передбачено викладання курсу "Управлінський облік".

У 1995 р. виходить друком перший навчальний посібник з управлінського обліку, автором якого став український професор М.С. Пушкар. На загальнодержавному рівні термін "управлінський облік" було закріплено Законом України "Про бухгалтерський облік і фінансову звітність в Україні".

У цей період системі управління приділяється дедалі більша увага, а вибору методу управління надається особливе значення, до кола інтересів менеджерів все частіше потрапляє управлінський облік. Процес становлення управлінського обліку простежується у двох напрямах американському та європейському. Відмінність між ними полягає в тому, що в англоамериканській практиці управлінський облік існує незалежно від фінансового й націлений на оперативний контроль за витратами, а в європейській виробнича та торгова бухгалтерії взаємно доповнюють одна одну і спрямовані на обчислення собівартості продукції.

На сучасному етапі в підсистемі управлінського обліку постають проблеми методологічного та методичного характеру щодо забезпеченості інформацією системи управління, оскільки, за даними досліджень, у загальному обсязі економічної інформації, представленої управлінським обліком, 50\% і більше не використовується при прийнятті рішень. Занадто деталізована інформація, без чітко вибудуваної структури, не лише ускладнює їх обробку та передачу, а й часто $є$ перепоною для прийняття своєчасних управлінських рішень.

Висновки. Отже, у результаті дослідження можна зробити висновок, що в сьогоднішніх умовах ведення бізнесу бухгалтерський облік не забезпечує інформацією всі стадії управління: аналіз, контроль, планування, прогнозування. Використання інформації бухгалтерського обліку менеджерами усіх рівнів управління обмежується через складність розуміння економічного змісту та взаємозв'язку статей і форм управлінської звітності.

Таким чином, дослідження історичної еволюції управлінської складової обліку дозволило виявити закономірності його становлення та сприяло виокремленню шести етапів його розвитку в управлінні (рис. 2).

Етап 1.

Започаткування бухгалтерського обліку в управлінні (до XV ст.)

\section{Етап 2.}

Становлення бухгалтерського обліку в управлінні (XV - кінець XIX ст.)

Етап 3.

Період розвитку базового бухгалтерського обліку в управлінні (кінець ХIX ст. -30 рр. ХX ст.)

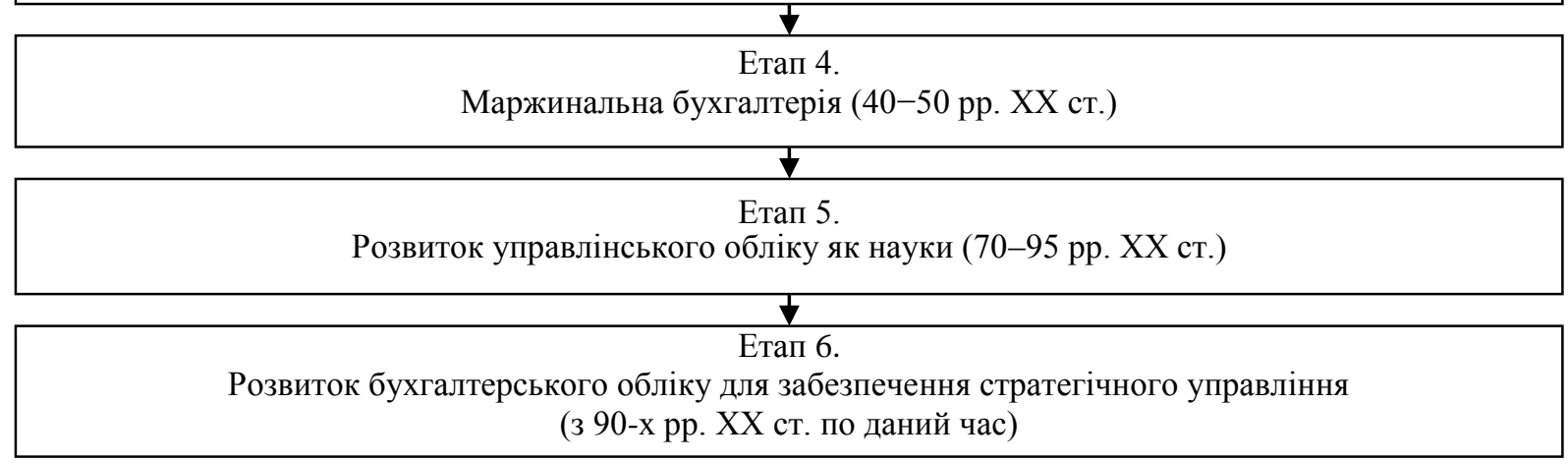

Рuc. 2. Етапи еволюції бухгалтерського обліку в управлінні

Джерело: власна розробка автора

Виділені етапи становлення бухгалтерського обліку віддзеркалюють розвиток його організації й методології в управлінні, тим самим засвідчуючи появу нових постійно зростаючих вимог як до обліку, так і до його даних. 
Останній етап розвитку обліку в управлінні - "Розвиток бухгалтерського обліку для забезпечення стратегічного управління" - засвідчив появу нових запитів до облікової системи, специфіка яких і зумовила ії перебудову. Цей етап характеризується наділенням бухгалтерського обліку та його інформаційних масивів вирішальною роллю у забезпеченні потреб не лише оперативного, але й стратегічного управління. У той же час спрямованість управлінських запитів та їхній динамізм свідчать про відставання практики обліку від потреб менеджменту.

\section{Список використаної літератури}

1.Галаган А.М. Накладные расходы в производстве, методы их учета и распределения. Система и организащия. 1924. №10. С.45-48. C. $18-23$.

2. Дмитриев М.В. Развитие промышленного учета в СССР. Бухгалтерский учет. 1967. №10.

3. Лучко М.Р. Історія обліку: Світ та Україна, погляд крізь роки. Тернопіль: "Зорепад", 1998. 150 с.

4. Мэтьюс М.Р., М.Х.Б. Перера. Теория бухгалтерского учета: учебник. Москва: Аудит, ЮНИТИ, 1999. 664 с.

5. Нидлз Б., Андерсон, Д. Колдуэлл. Принципы бухгалтерского учета Москва: Финансы и статистика, 2004. 496 с.

6. Николаева С.А. Особенности учета затрат в условиях рынка: система "директ-костинг": Теория и практика. Москва: Финансы и статистика, 1993. 128 с.

7. Пачоли Л. Трактат о счетах и записях / Под ред. проф. Я.В. Соколова. Москва: Финансы и статистика, $1982.286 \mathrm{c.}$

8. Рудановский А.П. О калькуляции. Вестник счетоводства. 1924. № 9-10.

9. Соколов Я.В. История развития бухгалтерского учёта : монография. Москва, Финансы и статистика, 1985. $368 \mathrm{c.}$

10. Чумаченко Н. Г. Учет и анализ в промышленном производстве США. Москва: Финансы, 1971. $238 \mathrm{c}$.

11. Энциклопедический словарь бизнесмена: менеджмент, маркетинг, информатика / под общ.ред. М.И. Молдованова. Киев:"Техніка", 1993, 856 с.

12. Growningshield G.R. and Batista G.L. The Accounting revolution Management Accounting. 1996. P. 36.

\section{References}

1. Galagan A.M. (1924). Nakladnye rashody u proisvodse, motody ux ychuta i raspredelenie [Overhead costs in production, methods for their accounting and distribution]. Sistema i organisaziya (pp. 45-48).

2. Dmitriev V. (1967). Rasvitie promychlennogo ychuta u USSR [Development of industrial accounting in the USSR]. Bukhhalterskyi oblik (pp. 18-23).

3. Luchko M.R., \& Ostap'yuk M.J. (1998). Historia obliky: Svit ta Ucraina, poglyad kris roku [Ratione historia: Mundi et Ucraina, in sententia per annos]. Ternopil: Sorepad [in Ukrainian].

4. Mэtyus M.R., \& Perera M.H.B. (1999). Teoriya Bukhhalterskogo ycheita [Theory of accounting]. Moscow: Audit, Yniti [in Russian].

5. Nydlz B. Anderson X., \& Kolduэll D. (2004). Principia buhhalterskoho uchëta [Principles of accounting]. Moscow: Finance i statistica [in Russian].

6. Nikolaeva S.A. (1993). Osobenosti uchëta satrat u yslovie runka: sistema "direct costing": Theoria Practice [Features of cost accounting in the market conditions: the system of "Direct-Costing": Theory and practice]. Moscow: Finance i statistica [in Russian].

7. Pacioli L., \& Sokolov V. (1982). Traktakt o schetax i sapicayx [Treatise on accounts and records]. Moscow: Finance i statistica [in Russian].

8. Rudanovskaya A.P. (1924). In kalkulyatsyy [About costing]. Vestnik schetovodstva.

9. Sokolov J. (1985). De historia razvytyya buhhalterskoho uchëta [monografia] [History of accounting development: [monograph]]. Moscow: Finance i statistica [in Russian].

10. Chumachenko N.G. (1971). Uchët i analysis u promushlennom proyzvodstve USA [Accounting and analysis in the US industrial production]. Moscow: Finance i statistica [in Russian].

11. Moldovanova M.Y. (1993). Эntsyklopedycheskyy slovar byznesmena: menedzhment, marketynh, ynformatyka / pod obsch. red. [Encyclopedic Dictionary of a Businessman: Management, Marketing, Informatics]. Kyiv: "Technology" [in Ukrainian].

12. Growningshield G.R. and Batista G.L. (1996). Et Accounting revolution Accounting Management [The Accounting revolution Management Accounting]. 
Інформація про авторів

ПРОДАНЧУК Михайло Андрійович - доктор економічних наук, доцент, Відмінник освіти України, ННЦ «Інститут аграрної економіки» НААН України,(Україна, 03127, м. Київ, вул. Героїв Оборони, 10, e-mail: Prodanchukma@gmail.com)

PRODANCHUK Mykhailo - Doctor of Economic Sciences, Associate Professor of State Audit and Control Department NSC "Institute of Agrarian Economics" NAAS of Ukraine (Ukraine, 03127, m. Kyiv, st. Heroes of Defense, e-mail: Prodanchukma@gmail.com)

ПРОДАНЧУК Михаил Андреевич -, доктор экономических наук, доцент, Отличник образования Украины, ННЦ «Институт аграрной экономики» НААН Украины, (Украина, 03127, г. Киев, ул. Героев Обороны, 10, e-mail: Prodanchukma@gmail.com)

\section{УАК 657:006.3:631.115.71}

\section{СКЛАД ТА ОЦІНКА БІОЛОГІЧНИХ АКТИВІВ ЗГІАНО 3 НАЦІОНАЛЬНИМ ПОЛОЖЕННЯМ (СТАНААРТОМ) БУХГАЛТЕРСЬКОГО ОБЛІКУ В АЕРЖАВНОМУ СЕКТОРI 136 “БІОЛОГІЧНІ АКТИВИ" $\odot$}

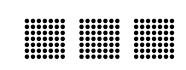

У статті розглянуті актуальні проблеми впровадження національного положення (стандарту) бухгалтерського обліку в державному секторі 136 “Біологічні активи”. Досліджено сутність поняття "біологічні активи" в різних наукових і літературних джерелах. Розглянуто різні наукові підходи до визначення біологічних активів. Наведено класифікацію біологічних активів для изілей бухгалтерського обліку залежно від тривалості виробничого процесу та періоду отримання сільськогосподарської продукиї. Досліджено особливості оцінки біологічних активів залежно від ӥх надходження; проблемні моменти щзодо обліку довгострокових біологічних активів, які використовуються в процесі діяльності, щуо не пов'язана із сільськогосподарською діяльністю; виділено основні проблеми, які виникають у суб’єктів державного сектору при їх оцінці, зокрема в аспектах визначення справедливої вартості таких активів, зазначено основні недоліки оцінки за справедливою вартістю. За результатами проведеного дослідження у статті зроблені відповідні висновки.

Ключові слова: національні стандарти бухгалтерського обліку в державному секторі, біологічні активи; облік; визнання біологічних активів; оцінка біологічних активів, справедлива вартість, оцінка на дату балансу.

Табл.:1. Рис.:2. Літ.:16.

\section{COMPOSITION AND ASSESSMENT OF BIOLOGICAL ASSETS ACCORDING TO NATIONAL ACCOUNTING STANDARDS (PUBLIC SECTOR ACCOUNTING STANDARDS) 136 "BIOLOGICAL ASSETS"}

KYTAICHUK Tatiana, Candidate of Economic Sciences, Associate Professor of the Accounting and Taxation, Vinnytsia Institute of Trade and Economic of Kyiv National University of Trade and Economics

(Vinnytsia)

The article deals with the actual problems of implementation of the national provision (standard) of accounting in the public sector 136 "Biological Assets". The essence of the concept of "biological assets" in various scientific and literary sources was investigated. Different scientific approaches to the definition 